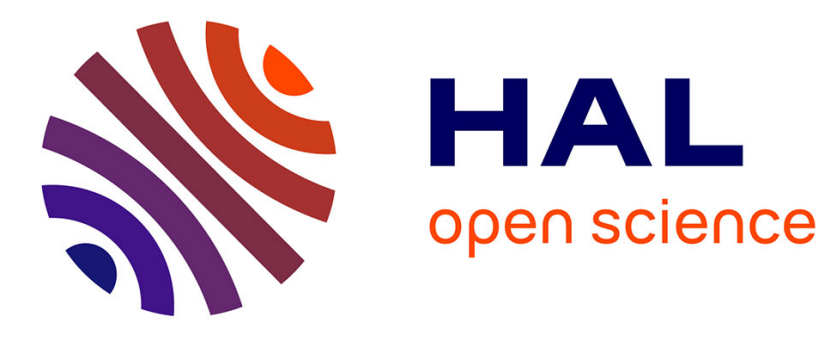

\title{
The Complexity of Xenakis's Notion of Space
}

Makis Solomos

\section{To cite this version:}

Makis Solomos. The Complexity of Xenakis's Notion of Space. In Martha Brech et Ralph Paland, Technische Universität, Berlin, juillet 2014, publiée dans Martha Brech, Ralph Paland (éd.), Komposition für hörbaren Raum. Die frühe elektroakustische Musik und ihre Kontexte / Compositions for Audible Space. The Early Electroacoustic Music and its Contexts, Bilefeld, transcript Verlag, 2015, p. 323-337., 2015, 10.14361/9783839430767-020 . hal-01202884

\section{HAL Id: hal-01202884 \\ https://hal.science/hal-01202884}

Submitted on 21 Sep 2015

HAL is a multi-disciplinary open access archive for the deposit and dissemination of scientific research documents, whether they are published or not. The documents may come from teaching and research institutions in France or abroad, or from public or private research centers.
L'archive ouverte pluridisciplinaire HAL, est destinée au dépôt et à la diffusion de documents scientifiques de niveau recherche, publiés ou non, émanant des établissements d'enseignement et de recherche français ou étrangers, des laboratoires publics ou privés. 


\title{
The Complexity of Xenakis's Notion of Space
}

\author{
MAKIS SOLOMOS
}

\section{Abstract}

The notion of space is crucial to Xenakis's music and thought. This chapter will offer a global approach, trying to show the complexity and inner richness of this notion. Indeed, there are at least four levels where we can found it. First, there is the ontological and philosophical level. On that level, space is a fundamental notion for Xenakis. In the 1960s he created the notion of »outside-time structures «, which minimizes the importance of time, and in the 1980s he stated that time could be viewed as an epiphenomenal notion, while space would be more fundamental. On a second level, we could view space as an operative category. The discourse will be about geometric space, and, for instance, the use of graphs for composing music. It is thanks to this kind of space that Xenakis imagined new types of sound morphologies (glissandi, for instance) or that he invented transfers from the microscopic level to the macroscopic. With the third level, we are in the domain of the physical space, where Xenakis was one of the main pioneers, introducing the idea of the »composability « of physical space. It is what happened in the Philips Pavilion of the Brussels World Fair (Expo 58) with the »sound routes «, or with the sound immersion produced with Bohor (1962), or with the metaphor of the »Sonotron « used in Terretektorh (1965-66), etc. With the fourth and final level we can define space as a place where an event occurs: this is the definition of the Xenakian notion of »polytope $\ll$. 


\section{INTRODUCTION}

Xenakis is often described as a »space« composer. When saying that, we think of the three-dimensional quality of his music, which works with sound masses and juxtaposition of textures, and which has a quasi-tactile dimension - in a way, Xenakis is a »sound sculptor «. But we also think of the fact that he was one of the first composers to work with sound spatialization both in instrumental music and in electroacoustic music, putting the listener inside an orchestra (Terretektorh), realizing complex, automated spatializations of electroacoustic sounds (the Polytopes), etc. There are also other domains where the notion of space can be inferred from Xenakis's music and thought.

In fact, the notion of space itself, as it is used in music - as well as in many other fields - has many senses; as the French writer Georges Perec would say, there are »spaces of space «. There is, for instance, an opposition between physical space and metaphorical space (or space as a tool for representation); there is also an opposition between virtual and real space; space can be used as »immersion « or, on the contrary, for constructing localizations; and so on. ${ }^{2}$

Thus Xenakis's thought can help us to analyse the various aspects of space in music. In this chapter, we will see that we can define at least four different notions of space: the first notion concerns the philosophical level, in relationship to the ideas of time and energy; the second notion is rooted in the compositional level; the third is related to physical space; and finally, the fourth notion appears when physical space becomes place.

\section{Time, SPACE, AND ENERGy}

First, there is a philosophical or ontological level, where space is, for Xenakis, a crucial notion. Let's start with Xenakis's philosophy of time. He acknowledges the centrality of unmeasured time, i.e. the pure time flow. He even thinks of it almost as an equivalent to music itself:

1 Georges Perec, Espèces d'espaces, Paris 1974.

2 In my recent book (De la musique au son: L'émergence du son dans la musique des XXe-XXIe siècles, Rennes 2013), I explore some of the meanings of space in music, in particular in Chapters 3 (»Immersion«) and 6 (»Sound-Space «). 
»When you use tools like paper while writing and conceiving musical forms, you can think in terms of spatial qualities, but that is less important during composition itself. Music develops in time. [...] Musical time can't be reduced to a stopwatch. [...] The exact measurement, in seconds, of musical time and durations is of little interest. [...] It is the interior of time that counts, not its absolute duration. [...] Time is independently and simultaneously articulated by various musical events. $\ll^{3}$

Xenakis makes a difference between >flow $<$ and >duration $<$, meaning unmeasured and measured time. Only the latter is reversible:

»A duration is something that can be moved around within time, it is therefore reversible, commutative. [...] The difference between any two points is a concept which stems from comparisons and mysterious judgments I make about the reality of the temporal flow, which I accept $a$ priori. The distance between the two points is what is then identified as a duration. I displace this duration anywhere; therefore, it is reversible. But the temporal flow itself is irreversible. ${ }^{4}$

In these lines, the phrase »mysterious judgments I make about the reality of the temporal flow, which I accept a priori « is crucial. Xenakis admits that he does not know what time is (time flow). In one of the latest interviews, he says: $\gg I$ never understood what is time. Time remains something mysterious for me. Time is everywhere, it rains, it snows ${ }^{5}$, it is part of nature. This is why I cannot understand what time is. ${ }^{6}$

That may explain why he focused more and more on measured time - time that can be >constructed $<$ : »There is the temporal flow, which is an immediate given, and then there is metrics, which is a construction man makes upon time ${ }^{7}$. He often defines time (time flow) as an empty blackboard: »Time could be considered as a blank blackboard, on which symbols and relation-

3 Iannis Xenakis interviewed by Anne-Maria Harley, »Musique, espace et spatialisation«, in: Circuits 5/2 (1994), pp. 9-20, here p. 13.

4 Iannis Xenakis, Arts/Sciences: Alloys, translated from French by Sharon Kanach, Hillsdale (N.Y.) 1985 (originally published as Arts/Sciences: Alliages, Tournai 1979), pp. 74-75.

5 The French word temps means both >time< and > weather $<$.

6 Omer Corlaix and Bastien Gallet, »Entretien avec Iannis Xenakis«, in: Musica Falsa No. 2, Paris 1998, p. 29.

7 Iannis Xenakis, Arts/Sciences, op.cit., p. 97. 
ships, architectures and abstract organisms are inscribed $\ll^{8}$. There, time is an abstract dimension enabling one to ask the question of time in terms of construction. Therefore, when he says that time is the same as music, it would be >measured time< that he means, not >time flow<. This contrasts sharply with the centrality of unmeasured time in the philosophy of Henri Bergson (although Bergson's word for unmeasured time was >duration<). Xenakis is more interested in the possibility of making, building, or constructing something within time (or, upon time). We might even say that he aims to >construct< time. It is no surprise, then, that during the 1960s and 1970s he had a strong interest in Jean Piaget:

»Piaget's book provided me with my first justification that I was right to do calculations with time. He proved that the perception of time stopped developing at the age of twelve. Up until the age of six one can't see this process clearly, but between six and twelve I think there are three stages. He showed that time has an ordering structure and that time intervals can be added and permutated, and consequently that they have a group structure. I concluded from all this that time is nothing but a kind of structure. And because it is a structure it can be counted, expressed with real numbers, and shown as points on a straight line. $\ll^{9}$

In the 1960s, Xenakis spoke of >amnesia<. The chapter of Musiques Formelles devoted to »symbolic music « begins, »we shall begin by imagining that we are suffering from a sudden amnesia. ${ }^{10}$ We shall thus be able to reascend to the fountain-head of the mental operations used in composition and attempt to extricate the general principles that are valid for all sorts of music. ${ }^{11}$ In a sense, we may say that Xenakis $>$ fights $<$ with time. And, anyway, we should not forget his notion that the temporal dimension also includes »outside-time« structures. »Whatever we think is by definition outside time because it is in our memory and doesn't disappear with the passage of time (unless we forget it). We have no power over the time-flow but we feel it passing: the notion of time is also outside time. $\ll^{12}$

8 Iannis Xenakis, Formalized Music, edited by Sharon Kanach, Hillsdale (N.Y.) 1992, p. 192.

9 Bálint András Varga, Conversations with Iannis Xenakis, London 1996, pp. 82-83.

10 Original French: »Nous commencerons par nous considérer brusquement amnésiques.«

11 Iannis Xenakis, Formalized Music, op.cit., p. 155.

12 Bálint András Varga, op.cit., p. 83. 
Elsewhere, Xenakis considers time as an epiphenomenon, and space as a more fundamental reality. On this, we should carefully look into Xenakis's only article explicitly devoted to the issue of time. ${ }^{13}$ The beginning reads: »Isn't time simply an epiphenomenal notion of a deeper reality? Thus an illusion that we unconsciously have accepted since our earliest years and even since the earliest, ancient ages? ${ }^{14} \mathrm{He}$ then hypothesizes that >displacement is a more fundamental notion, adding that »if the notion of displacement were more fundamental than that of time, one could undoubtedly reduce all macro- and microcosmic transformations to extremely short chains of displacement. ${ }^{15}$ Furthermore, referring to the experiment of »correlation of the movement of two photons emitted in opposite directions by a single atom «, ${ }^{16}$ he notes,

»Now, this experiment could be a starting point for the investigation of more deeply seated properties of space, freed from the tutelage of time. In this case, could the >nonlocality of quantum mechanics be explained perhaps not by the hypothesis of shidden variables < in which time still intervenes, but rather by the unsuspected and extravagant properties of nontemporal space, such as >spatial ubiquity<, for example? ${ }^{17}$

Yet, not even space seems to be the ultimate reality. Xenakis's preliminary conclusions, in fact, are as follows:

»As space is perceptible only across the infinity of chains of energy transformations, it could very well be nothing but an appearance of these chains. In fact, let us consider the movement of a photon. Movement means displacement. Now, could this displacement be considered an autogenesis of energy, an energetic parthenogenesis of the photon by itself at each step of its trajectory (continuous or quantized)? This continuous auto-creation of the photon, could it not, in fact, be space? ${ }^{18}$

13 Iannis Xenakis »Sur le temps« (1988), reprinted in: idem, Kéleütha, edited by Alain Galliari, preface and notes by Benoît Gibson, Paris 1994, p. 94; Chapter 10 of Formalized Music, op.cit, is closely related to this article.

14 Iannis Xenakis, »Sur le temps«, op.cit., p. 94.

15 ibidem; cf. Iannis Xenakis, Formalized Music, op.cit., p. 256.

16 ibidem; cf. Iannis Xenakis, Formalized Music, op.cit., p. 257.

17 ibidem; cf. Iannis Xenakis, Formalized Music, op.cit., p. 257.

18 ibidem; cf. Iannis Xenakis, Formalized Music, op.cit., pp. 257-258, incomplete. 


\section{Space as an Operative Category}

Let us now analyse a second level, where the question is about >geometrical< space, and, for instance, the use of graphs for composing music. It is thanks to this kind of space that Xenakis invented new types of sound morphologies (for instance, the morphology of massive glissandi) or that he invented transfers from the microscopic to the macroscopic time level. More generally, we could say that, in this context, space is a tool for representing and composing music, and thus an operative category.

It is interesting to notice that, in one of his very few attempts to analyze music that was not composed by himself, Xenakis used algebraic space. I refer to his analysis of Ludwig van Beethoven's Appassionata in Musiques Formelles (see Figure 1).

Figure 1: Analysis of Beethoven's Appassionata

The following is an analysis of a fragment of Sonata, Op. 57 (Appassionata), by Beethoven (see Fig. VI-1). We do not take the timbre into account since the piano is considered to have only one timbre, homogeneous over the register of this fragment.

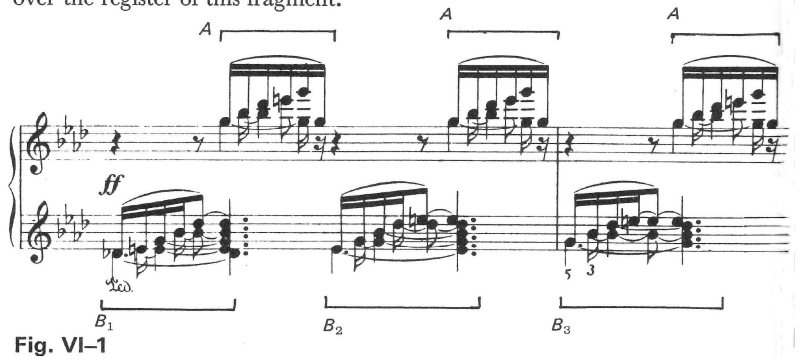

Assume as unit vectors: $\bar{h}$, for which $1 \hat{=}$ semitone; $\bar{g}$, for which $1 \hat{=} 10 \mathrm{~d} b$; and $\bar{u}$, for which $1 \hat{=} \&$. Assume for the origins

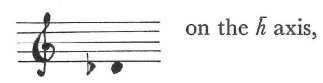

$$
\begin{aligned}
& f f=60 d b \text { (invariable) on the } \bar{g} \text { axis, and } \\
& 5 \S \text { on the } \bar{u} \text { axis. }
\end{aligned}
$$

Algebra outside-time (operations AND Relations in Set $A$ )

The vector $\bar{X}_{0}=18 \bar{h}+0 \bar{g}+5 \bar{u}$ corresponds to $G$.

The vector $\bar{X}_{1}=(18+3) \bar{h}+0 \bar{g}+4 \bar{u}$ corresponds to $B b$.

The vector $\bar{X}_{2}=(18+6) \bar{h}+0 \bar{g}+3 \bar{u}$ corresponds to $D b$.

The vector $\bar{X}_{3}=(18+9) \hbar+0 \bar{g}+2 \bar{u}$ corresponds to $E$.

The vector $\bar{X}_{4}=(18+12) \bar{h}+0 \bar{g}+1 \bar{u}$ corresponds to $G$.

The vector $\bar{X}_{5}=(18+0) \bar{h}+0 \bar{g}+1 \bar{u}$ corresponds to $G$. 
As for his own music, the most radical utilization of a geometrical space can be found in Nomos alpha (1965-66, for cello), where Xenakis uses the group model (in the mathematical sense) of a cube and its 23 rotations (see Figure 2). More generally, Xenakis used space in the geometrical sense as a way to understand music and to compose it, as shown by Peter Hoffmann. ${ }^{19}$

Figure 2: The group model (a cube and its 23 rotations) used in »Nomos alpha«

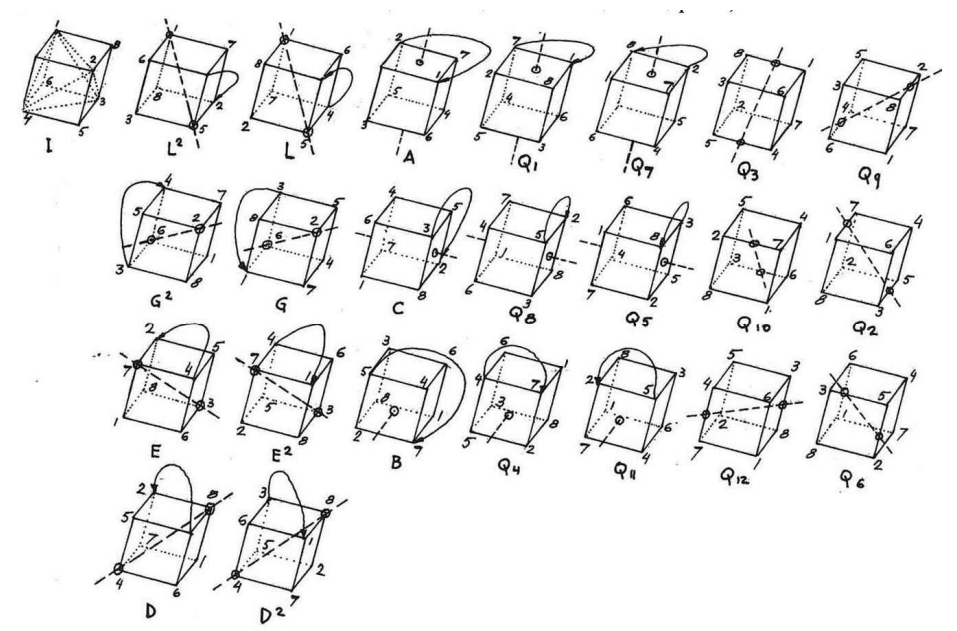

Iannis Xenakis, Musique, Architecture, Tournai 1971, p. 98

Xenakis's use of graphs for composing is a special case. As is well known, it is due to these kinds of graphs that he invented the notion of massive glissandi - a totally new sound morphology in the mid-1950s - such as those found at the end of Metastaseis (see Figure 3). The graph tool allowed him to develop his own vision of global sound phenomena, of masses of microsounds, which, owing to their complex interlocking, form a new global sound.

This is, of course, related to his experience in architecture. As Xenakis writes:

19 Peter Hoffmann, »L'espace abstrait dans la musique de Iannis Xenakis«, in: L'espace: Musique/Philosophie, edited by Jean-Marc Chouvel and Makis Solomos, Paris, pp. 141-152 (German translation: »Weltlinie im musikalischen Universum: Abstrakte Räume in der Musik von Iannis Xenakis«, in: MusikTexte No. 90, Köln, 2001, pp. 23-29. 
»In music, you begin with a theme or a melody and then you have a whole arsenal at your disposal that is more or less given for developing elaborations, be they polyphonic or harmonic (this applies as much to a classical sonata as a piece of serial music). You start from the mini to attain the global. In architecture, however, you must simultaneously conceive the details and the ensemble, otherwise, it all falls apart. This approach, this experience at Le Corbusier's studio and side with him obviously influenced me (even though I sensed it all along), or at least helped me conceive my music like an architecture project: globally and in detail at the same time. What constitutes architecture's force is these proportions: the coherent relationship between details and the whole $[\ldots] . \ll^{20}$

Figure 3: Xenakis's graph for the first version of the end of »Metastaseis«

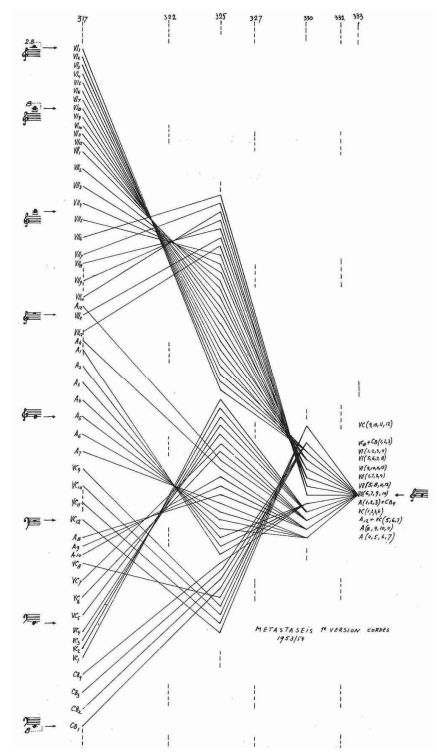

Iannis Xenakis, Musique, Architecture, op.cit., p. 8

It is also thanks to graphs that Xenakis moves from »microtime « to »macrotime «, such as those that gave birth to his notion of Brownian motion. In the end of the 1960s in Bloomington, Xenakis started investigating stochastic sound synthesis with random walks (in the mathematical sense of the term), producing graphs such as the one shown in Figure 4. In these graphs, it is a

20 Iannis Xenakis, Music and Architecture, edited by Sharon Kanach, Hillsdale (N.Y.) 2008 , p. 72. 
question of microtime. At the beginning of the 1970s, since he did not have access to sufficiently powerful computers to synthesize sound on the basis of the graphs, he used them to compose instrumental music instead. The first work composed with Brownian motions is Mikka (1971, for solo violin): Xenakis used stochastic sound pressure curves and changes the coordinates, computing macrotime instead of microtime. ${ }^{21}$

Figure 4: Stochastic sound pressure

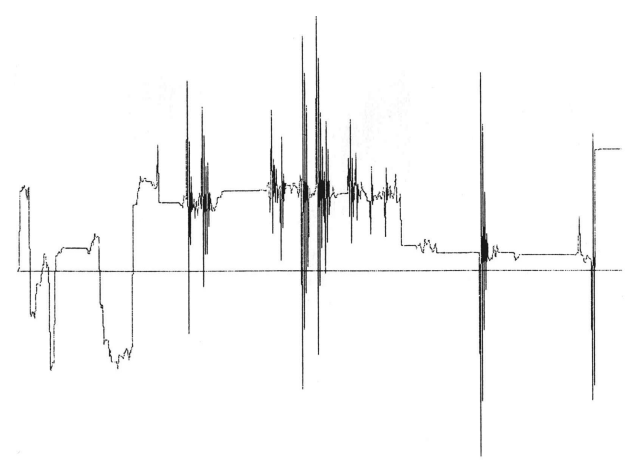

Iannis Xenakis, Formalized Music, op.cit., p. 251)

\section{Physical Space - Sound Spatialization}

The third level is the physical notion of space, which is related to sound spatialization. In this domain, Xenakis, after Edgard Varèse and around the same time as Karlheinz Stockhausen, is an important pioneer of this notion, which became increasingly important for music. Xenakis began very early to work with the idea that physical space can be composed. This can already be seen in his orchestral work Pithoprakta (1955-56): the >grains< of the piece's beginning (string players striking the body of their instruments) move from one group to another; and at the end of the piece, the strings come to play a single note, which travels from one group to another. Of course, the composition of space is most important in the 1958 composition Concret $\mathrm{PH}$, the

21 Cf. Makis Solomos, »The Unity of Xenakis's Instrumental and Electroacoustic Music: The Case of >Brownian Movements««, in: Perspectives of New Music 39(1) (2001), pp. 244-254. 
»instrumental interlude « of musique concrète composed by Xenakis to be played with Poème électronique. Here Xenakis designed the complex »sound routes « that spatialized sound using the over 400 loudspeakers available. In the same year he published the article »Notes towards an $>$ Electronic Gesture $\ll^{22}$, which reviews the experience of the performance given in the Philips Pavilion and puts forward new proposals for sound spatialization.

In 1962, Bohor is one of the first compositions to treat space in the sense of immersion. This electroacoustic work was composed for four two-track tape recorders, which, during the concert, were launched at the same time, inevitably became desynchronized. These desynchronizations were not >errors < because the idea was not to realize >travels< of sound from one loudspeaker to another, as in the Poème électronique, but to totally immerse the listener - it is also why Xenakis performed the piece extremely loudly. In 1963-1964, Eonta (for five brass instruments and piano) uses space, this time with a concern for staging: the instrumentalists (brass) are sometimes required to move and change their position in the concert hall.

Then, with the orchestral works Terretektorh (1965-1966) and Nomos gamma (1967-1968), the research into space became even more important and came to have a quasi-political meaning. Xenakis upsets the world of the orchestra and its audience by having the orchestra leave the stage; the musicians are distributed around the hall and the audience is placed inside the orchestra! Figure 5 shows the well-known layout of the orchestra in Terretektorh.

It is also important to quote Xenakis's note program:

»The scattering of the musicians brings in a radically new kinetic conception of music which no modern electro-acoustical means could match. For if it is not possible to imagine 90 magnetic tapes relaying to 90 loudspeakers disseminated all over the auditorium, on the contrary it is quite possible to achieve this with a classical orchestra of 90 musicians. The musical composition will thereby be entirely enriched throughout the hall both in spatial dimension and in movement. The speeds and accelerations of the movement of the sounds will be realized, and new and powerful functions will be able to be made use of, such as logarithmic or Archimedian spirals, in-time and geometrically. Ordered or disordered sonorous masses, rolling one against the other like waves. . . etc., will be possible.

Terrêtektorh is thus a >Sonotron $<$ : an accelerator of sonorous particles, a disintegrator of sonorous masses [...]. It puts the sound and the music all around the listener and

22 Iannis Xenakis, Music and Architecture, op.cit., pp. 131-134. 
close up to him. It tears down the psychological and auditive curtain that separates him from the players when positioned far off on pedestal, itself frequently enough placed inside a box. The orchestral musician rediscovers his responsibility as an artist, as an individual. $\ll^{23}$

\section{Figure 5: Terretektorh's orchestra}

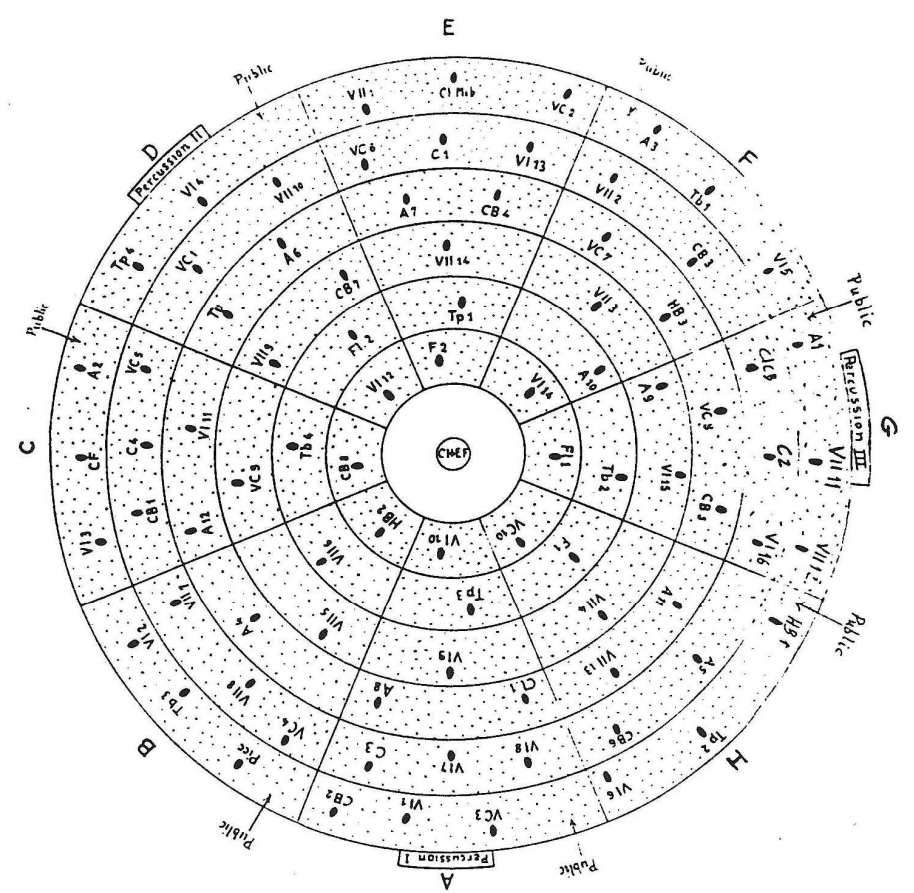

Iannis Xenakis, Terretektorh, score, Salabert editions

It is in Persephassa (1969, for six percussionists), where the six musicians surround the audience, that Xenakis's spatial composition culminates in the frame of instrumental music. It happens especially in the final part (bars 352-456) - a kind of amplification of the end of Nomos gamma - constituting a composition inside the composition, that John Batigne, a member of the Percussions de Strasbourg (the original performers of the piece), com-

23 Iannis Xenakis, Formalized Music, op.cit., pp. 236-237. 
pares to a >turnstile<, indicating that it was the most difficult part of the piece to perform without a conductor. ${ }^{24}$

Figure 6: Transcription of »Persephassa« (bars 352-456)
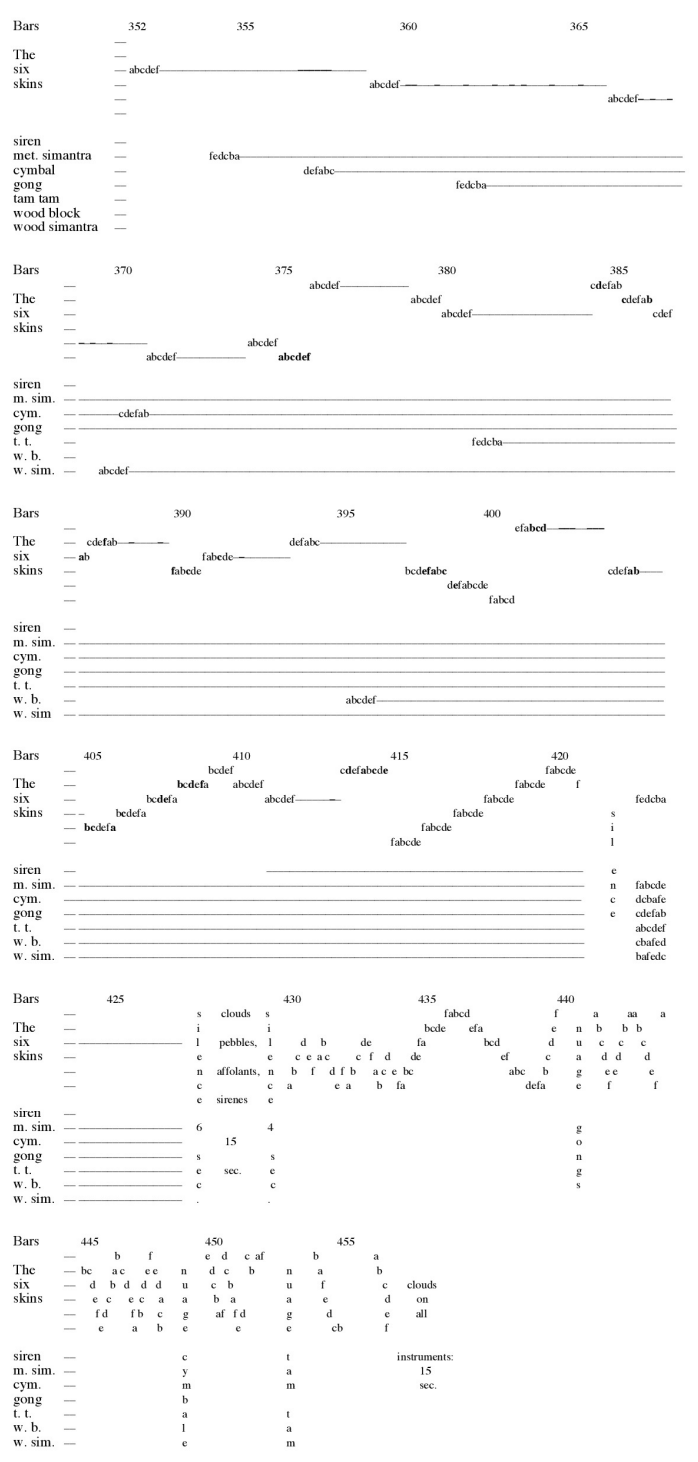

24 Jean Batigne, »Sur Persephassa et Pléiades«, in: Regards sur Iannis Xenakis, edited by Hugues Gerhards, Paris 1981, pp. 175-183, here p. 181. 
Figure 6 shows a transcription showing the spatial movement. Notice that this extract gives rise to an enormous accelerando and a giant crescendo (some high nuances that go beyond the overall crescendo are shown in boldface). As for the spatial movement, the six musicians (indicated by letters in the transcription) who have at their disposal six membrane instruments, siren, metal and wood Simantrons, cymbal, gong, tam-tam, and wood block, to which are added, towards the end of the piece, pebbles and affolants (thin steel sheets) transmit to each other a minim with a shift of a crotchet. The movement is twofold: one for the membrane instruments, the other for the remaining instruments (except the siren, which is not involved in this space game). The transcription (where a line indicates the continuation of the same figure) shows that the spatial motion goes through two phases. In bars 352 420 each membrane instrument enters gradually.

The spatial movement is circular: A-B-C-D-E-F for skins and for four other instruments, in reverse movement for the others. Bars 423-426, which follow after a general silence, constitute an area of disruption. After a >cloud < (improvised dense sounds with pebbles, affolants, and sirens) framed by two silences, only the membrane instruments remain in the spatial movement. First the initial circle is rebuilt (bars 430-439), but the membrane instruments change with each percussionist at both ends and with two, three or four in the middle. A >cloud < of gongs introduces a continual alternation of two circular directions and a sinusoidal path of (relative) pitches (bars 441-448). With a >cloud< of cymbals, the unique and reverse movement is restored bars (450-452). Finally, between a >cloud < of tam-tams and the long (15-second) conclusive >cloud < on all instruments, all types of spatial movement are deconstructed (B-A-F-E-D-C-B) very briefly (bars 454$455)$, and give rise to a single circle in the initial direction.

In Xenakis's subsequent instrumental production, space is far from absent (for example, in Retours-Windungen, 1976, for twelve cellos, or in Alax, 1985 , for three instrumental groups), but it is not used in such a striking manner. In fact, the >spectacular< aspect of space composition, which combines spatial trajectories and immersion, culminates with the Polytopes: Polytope de Montréal (1966-1967), Polytope de Persépolis (1971), Polytope de Cluny (1972-1974), Polytope de Mycènes (1978), and Diatope (Polytope de Beaubourg, 1978). ${ }^{25}$

25 The bibliography on Xenakis's sound spatialization is becoming increasingly important. Here a sampling of some extensive works on this topic: Helena Maria Da Silva Santana, L'orchestration chez Iannis Xenakis: l'espace et le rythme fonctions du 


\section{Space as Place: Polytopes}

The last notion of space concerns the Polytopes. In these multimedia (or intermedia) productions, we can speak about $>$ place $<$, i.e., a specific physical space and simply not any arbitrary physical space. Indeed, Xenakis realized each Polytope for a specific location, indicated in the Polytope's title. In a way, we could say that there is a single work, called »Polytope«, and that each precise polytope is a concretization of this work in a specific place. It is particular truth for the Polytope de Cluny and the Diatope: many aspects of the first (both in the visual spectacle and in the music) can be found in the second.

The most interesting feature of the idea of space as place is the position of the listening audience (Figure 7).

\section{Figure 7: Listener-spectators during Polytope de Cluny's performance}

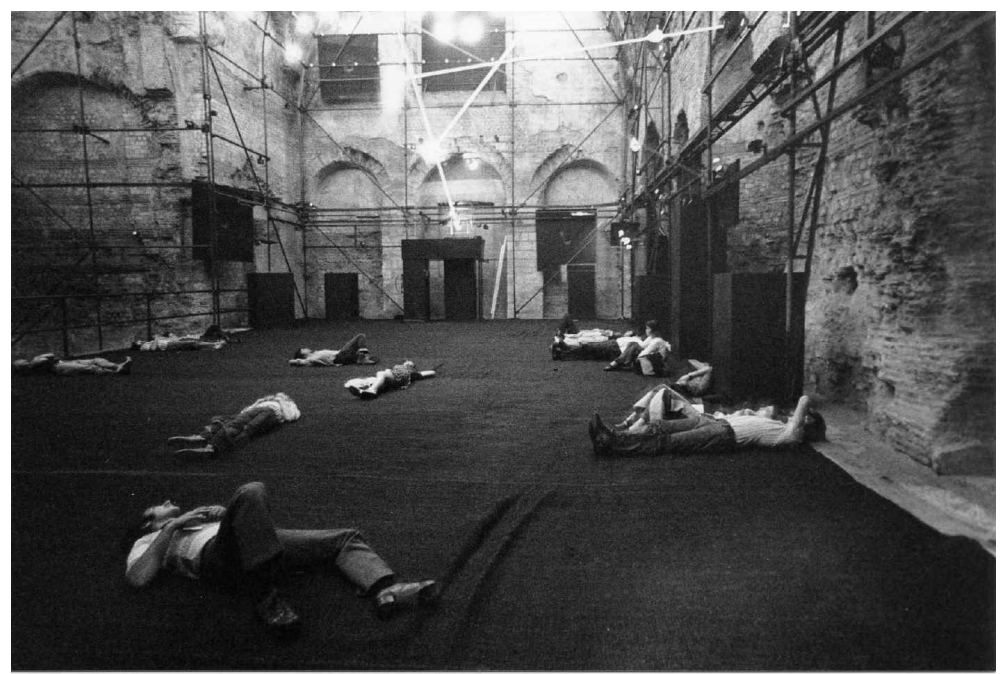

Archives Xenakis

timbre, Ph.D. dissertation, Université de Paris IV, Villeneuve D'Ascq 1999; Boris Hofmann, Mitten im Klang: Die Raumkompositionen von Iannis Xenakis aus den 1960er Jahren, Ph.D. dissertation, Technische Universität Berlin (= Sinefonia 10), Hofheim 2008; and Renaud Meric, »Concret PH, un espace mouvant«, in: 12e Journées d'Informatique Musicale 2005, edited by Anne Sedes and Horacio Vaggione, Paris 2005, pp. 147-155. 
We could compare this position with the position of the listeners in the wellknown painting »Beethoven and His Admirers« (Figure 8).

Figure 8: Albert Grafle, »Beethoven and His Admirers«

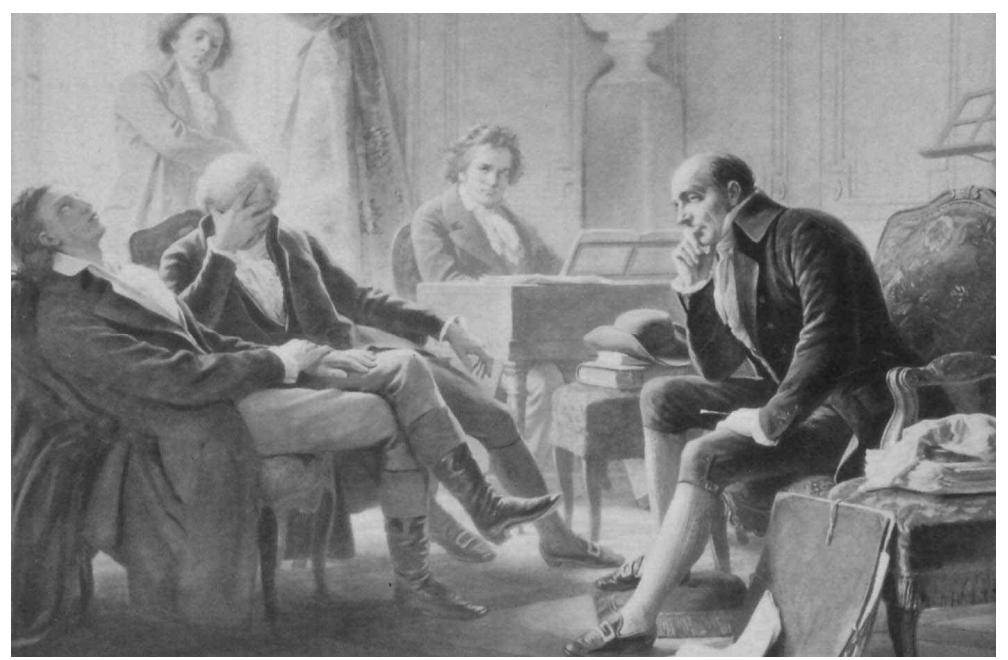

source?

More generally, Xenakis's idea that music and sound are deeply linked to space - and even more, to place - can be viewed as an antithesis to the idealistic aesthetics, which, if we follow Georg Wilhelm Friedrich Hegel, can be analysed as a negation of space:

»Mit dem Ton nun verläßt die Musik das Element der äußeren Gestalt und deren anschauliche Sichtbarkeit und bedarf deshalb zur Auffassung ihrer Produktionen auch eines anderen subjektiven Organs, des Gehörs, das wie das Gesicht nicht den praktischen, sondern den theoretischen Sinnen zugehört und selbst noch ideeller ist als das Gesicht. Denn die ruhige, begierdelose Beschauung von Kunstwerken läßt zwar die Gegenstände, ohne sie irgend vernichten zu wollen, für sich, wie sie da sind, ruhig bestehen, aber das, was sie auffaßt, ist nicht das in sich selbst Ideellgesetzte, sondern im Gegenteil das in seiner sinnlichen Existenz Erhaltene. Das Ohr dagegen vernimmt, ohne sich selber praktisch gegen die Objekte hinauszuwenden, das Resultat jenes inneren Erzitterns des Körpers, durch welches nicht mehr die ruhig materielle Gestalt, sondern die erste ideellere Seelenhaftigkeit zum Vorschein kommt. Da nun ferner die Negativität, in die das schwingende Material hier eingeht, einerseits ein Aufheben des räumlichen Zustandes ist, das selbst wieder durch die Reaktion des Körpers aufgehoben wird, so ist die Äußerung 
dieser zwiefachen Negation, der Ton, eine Äußerlichkeit, welche sich in ihrem Entstehen durch ihr Dasein selbst wieder vernichtet und an sich selbst verschwindet. Durch diese gedoppelte Negation der Äußerlichkeit, welche im Prinzipe des Tons liegt, entspricht derselbe der inneren Subjektivität, indem das Klingen, das an und für sich schon etwas Ideelleres ist als die für sich real bestehende Körperlichkeit, auch diese ideellere Existenz aufgibt und dadurch eine dem Innerlichen gemäße Äußerungsweise wird. ${ }^{26}$

That does not mean that Xenakis's aesthetic is >materialistic <, nor that in his music or in his Polytopes there is no longer anything called »meaning «! In fact, his aesthetics represent a break with the idealistic idea that the meaning of a musical or artistic work lays »behind « the sounds or the other physical media. This idea considerably reduced the possible meanings through a parallelism between music and language. As Luigi Nono clearly shows in an important discussion with Massimo Cacciari, the interest in physical space, as well as for place, in contemporary music can be interpreted as the need to re-introduce the multiplicity of meaning through the indissolubility of meaning and physical media-sound and space, when it is question of music (see Nono, 1993). Going back to Xenakis, we could say that it is not a coincidence that he gave us his most beautiful definition of music in the Diatope's program notes, his most accomplished polytope:

»Music is not a language. Every musical piece is like a complex rock formed with ridges and designs engraved within and without, that can be interpreted in a thousand different ways without a single one being the best or the most true. By virtue of this multiple exegesis, music inspires all sorts of fantastic imaginings, like a crystal catalyst. I, myself, wanted to deal with the abysses that surround us and among which we live. The most formidable are those of our own destiny, of life and death, of visible and invisible universes. The signs that convey these abysses to us are made up of lights and sounds that provoke our two predominate senses. This is why I have conceived the Diatope as a place for the condensation of these signs and signals from our various worlds. Rational knowledge blends with intuitive knowledge, or revelation. It is impossible to dissociate them. These abysses are unknowable; that is to say, knowledge of them is an eternal and desperate search, composed of milestones or hypotheses that have marked our various epochs. ${ }^{27}$

26 Georg Wilhelm Friedrich Hegel, Vorlesungen über die Ästhetik, III: »Das System der einzelnen Künste: Die Musik: Allgemeiner Charakter der Musik « http://www.textlog.de/hegel_aesthetik.html 1835-1838.

27 Iannis Xenakis, Music and Architecture, op.cit, p. 261. 
In this article, I have tried to show four different notions of space that we find in Xenakis's thought and artistic production: the philosophical level, where, for him, space is a more deep reality than time (but lesser deep than energy); the compositional level, where geometrical space is an operative category (materialized, for instance, in the graphs used by Xenakis to compose music); the physical level, where we speak about sound spatialization; and finally, a level with a more concrete notion of physical space, the level of what we can call >place<, and which allows us to understand the need for space in terms of aesthetics as a way to rediscover the multiplicity of meaning. 